\title{
AJARAN ETIKA ISLAM \\ DALAM PEMASARAN PRODUK MURABAHAH \\ (Studi pada Bank Muamalat Indonesia Cabang Malang)
}

\author{
Nur Asnawi \\ Fakultas Ekonomi Universitas Islam Negeri Maulana Malik Ibrahim Malang \\ Jl. Gajayana No. 50, Telepon (0341) 558881, Fax. (0341) 558881, \\ E-mail: feuinmlg@yahoo.co.id
}

\begin{abstract}
A lot of people on business community want to get maximal profit but in practice they ignore normative and ethic values. This condition becomes a life style in public and has grown as Al-Khub al-dunya, Al-takatsur, consumerism, and hedonism. The purpose of this research is to describe ethic comprehension of BMI community and its implication to murabahah product marketing. This research uses field research with qualitative approach. The result shows that BMI Malang branch understand to the importance of ethic application on business activity because it can support sustainable and establishment of the business. The implication of ethic comprehension is reflected in service to customer particularly on murabahah transaction. These service are friendly, honest without differentiate customer who comes to BMI Malang.
\end{abstract}

Key word: ethic, marketing, murabahah

Kecenderungan masyarakat dalam dunia bisnis menginginkan profit maksimal tanpa melihat banyak bagaimana nilai-nilai normatif transenden, nilai etika diajarkan dalam aktivitas perekonomian. Hal ini sebagaimana dikatakan oleh Muhaimin (2007), pola hidup yang berkembang dimasyarakat adalah alkhub al-dunya, al-takaatsur, konsumerisme, hedonisme yang menggiring masyarakat memisahkan nilai-nilai normatif yang bersifat ilahiyat (tauhid) dan insaaniyyaat (humanity). Di samping itu hal menarik saat ini adalah munculnya berbagai rumah ibadah, menjamurnya majlis ta'liim, majlis dzikir, meningkatnya masyarakat yang melakukan ibadah haji, namun di sisi lain terjadinya kemerosotan solidaritas sosial (Gani: 2006), rendahnya tertib hukum, miskin empati dan keberpihakan pada kaum dluafaa', serta menjamurnya model faham hedonisme yang berimplikasi perilaku ekonomi masyarakat. 
Implikasi faham di atas adalah sebagaimana realitas saat ini dunia bisnis timbul gejala menghalalkan segala cara demi mencapai tujuan untuk sebuah kenikmatan. Etika bersaing dalam bisnis tidak lagi tampil secara elegan, profesional dan sportif, namun cara dan budaya menerabas justru semakin tumbuh subur di tengah masyarakat. Salah satu penyebabnya adanya fenomena kepribadian yang terbelah (Gani: 2006), yakni masyarakat menempatkan agama sebagai wilayah pribadi terpisah dengan tanggung jawab sosial.

Globalisasi dan perubahan teknologi menciptakan persaingan usaha yang ketat, pasar menjadi semakin komplek dan tidak mudah ditebak, informasi yang mudah didapat menjadikan perusahaan dengan mudahnya mengakses informasi mengenai pesaing dan persaingan, perang yang terjadi di pasar menjadi semakin terbuka akibat pengaruh dari perkembangan komunikasi, karena tidak sedikit perusahaan dalam menghadapi persaingan sekarang ini berkembang mengarah pada praktek-praktek persaingan liar yang menghalalkan segala cara, nilai - nilai etika tidak lagi tampil secara elegan ditengah carut marutnya masyarakat dalam aktivitas perekonomian.

Sehingga masih banyak masyarakat memiliki paradigma bahwa perilaku bisnis dengan menggunakan tilikan etika Islam akan menghambat jalannya proses untuk mencari profit sebagai asas dalam berbisnis. Namun bila dilihat lebih dalam tentang penerapan nilai-nilai etika dalam perusahaan akan mengantarkan perusahaan semakin establish dan sustainable. Ungkapan ini senada dengan apa yang dikatakan oleh Key and Popkin (1998) dilibatkannya etika mempunyai keterkaitan dengan kinerja keuangan perusahaan yang dapat menjaga kinerja keuangan perusahaan untuk jangka panjang.

Salah satu produk perusahaan Bank Muamalat Indonesia yang sangat diminati masyarakat adalah produk Pembiayaan Murabahah, seiring mulai bergesernya paradigma pemasaran dari rasional marketing emosional marketing yang bermuara pada spiritual marketing. Transaksi murabahah yang paling banyak diminati oleh moslem mayority dilakukan dengan cara disamping sama-sama melakukan akad, barang yang dijual belikan bukan barang yang dilarang oleh syarii' at Islam, kemudian bank membiayai sebagian atau seluruh harga pembelian barang yang telah disepakati kualifikasinya dan sesuai dengan perjanjian hukum yang disepakati. 
Untuk melihat lebih jauh tentang nilai etika dalam pemasaran produk murabahah di Bank Muamalat Indonesia Cabang Malang serta implikasinya dalam dinamika perusahaan, peneliti memformulasikan penelitian ini dengan tema Ajaran Etika dalam Pemasaran Produk Murabahah (Studi pada Bank Muamalat Indonesia Cabang Malang).

Berdasarkan paparan di atas maka tujuan penelitian ini adalah mendeskripsikan pemahaman etika komunitas Bank Muamalat Indonesia dalam menjalankan pemasaran produk Murabahah Cabang Malang dan mendeskripsikan implikasi pemahaman etika terhadap pemasaran produk murabahah Bank Muamalat Indonesia Cabang Malang.

\section{MENYELAMI KERAGAMAN PEMIKIRAN ETIKA DALAM BISNIS}

Adakah perbedaan dan persamaan dari berbagai term diatas? Guido Maertens (1990) memberikan penegasan bahwa pada dasarnya etika adalah cabang dari filsafat yang mengenakan refleksi dan metode pada tugas Manusia untuk menemukan nilai-nilai moral yang menerjemahkan nilai-nilai itu kedalam norma-norma dasar (etika dasar) dan menerapkannya pada situasi kehidupan konkrit (etika terapan). Sehingga pertanyaan pokok dari etika adalah tindakan dan sikap apa yang dianggap benar atau baik.

Dalam konteks itulah tujuan dari etika yang menurut Peter Pratley (1997) memiliki tujuan ganda yakni menilai praktek-prektek manusiawi dengan menggunakan standar moral, dan juga mungkin memberikan nasehat yang jelas tentang bagaimana bertindak secara moral pada situasi tertentu, dapat kita ajukan guna mempertajam sisi dari etika tersebut. Lantas apa yang dimaksud moral dalam konteks ini? samakah ia dengan etika misalnya?

Banyak penulisan misalnya M. Amin Abdullah (1996), Ishomuddein (1998) memberikan penekanan yang sama antara term etika dengan moral. Sisi lain Fran Magis Suseno meskipun menyamakan asal arti kedua istilah itu, namun membedakan dalam menggunakannya. Menurutnya etika merupakan ilimu tentang norma-norma, nilai-nilai, ajarn-ajaran moral, sedangkan moral adalah rumusan sistimatik terhadap anggapan-anggapan tentang apa yang bernilai serta kewajiban-kewajiban manusia (Suseno, 1982). 
Istilah lain yeng sering identik dengan term etika dan moral adalah akhlak. Kata akhlak berasal dari bentuk jama' kata Arab Khuluq yang berarti budi pekerti atau perangai. Dalam banyak literature Islam akhlak diartikan dua macam: 1) pengetahuan yang menjelaskan arti baik dan buruk, tujuan perbuatan, serta pedoman yang harus diikuti, 2) Pengetahuan yang menyelidiki perjalanan hudup manusia sebagai parameter perbuatan, perkataan serta ikhwal kehidupannya (Ma'luf :1998).

Tanpa membuat perbedaan antar ketiga term dimuka, etika, moral dan akhlak memberikan penekanan yang pokok bagaimana perilaku, ucapan dan Ikhwal aktivitas kemanusiaan kita selalu dalam bingkai kebaikan dan dengan mengacu pada nilai-nilai idialitas yang harus kita aplikasikan dalam kegiatan kita sehari-hari. Dalam bahasa lain etika dan moral berfungsi menentukan batas perilaku dan menarik garis pemisah antara yang baik dan yang buruk antara benar dan yang tidak benar antara boleh dan yang tidak boleh. (Sondang P.)

Meski demikian dalam tataran sejarah, terutama dalam sejarah Islam wacana etika selalu mengandung perbedaan antara pro dan kontra yang berangkat dari titik tekan yang berbeda (Fakry, 1996). Menurutnya wacana seputar etika dalam Islam terbagi dalam kelompok tiga besar. Pertama, etika teologis. Aliran ini diwakili oleh kelompok-kelompok rasionalis semisal mu'tazilah, semirasionalis dan volunteris yang diwakili oleh As'ary, serta anti rasionalis yang diwakili oleh Ibn Hazm. Kedua, etika filosofis yang diwakili oleh Al Kindi, Al- Razi, Al- Farabi dan lain-lain. Ketiga, etika religius yang diwakili oleh Hasan Al- Bashri, Al- Mawardi dan lain-lain.

Sebagai contoh Al- Mawardi misalnya melihat permasalahan etika dalam dimensi Islam bukan hanya berdebat dalam term-term filosofis yang abstrak tentang apa itu baik dan buruk. Namun dalam presepsi dia, asensi dari wacana etika adalah bagaimana nilai-nilai yang terakumulasi dalam acuan-acuan wahyu dan acuan normative lainnya bisa terakumulasi dalam tataran riil kehidupan bermasyarakat. Sehingga dalam wacana sejarah Islam ia termasuk pendukung etika terapan dalam Islam.

Terlepas dari pluralitas wacana yang ada seputar etika ini, yang jelas persinggungan wacana etika dalam Islam sedikit banyak terilhami oleh wacana sebelumnya yang banyak dilakukan dalam tradisi Yunani - pikiran Plato 400 
SM. Persinggungan positif ini memberikan indikasi kuat, apapun budaya dan agama yang ada memiliki concern (kepedulian) yang kuat bagaimana nilai-nilai positif yang sebenarnya inhern di dalam fitrah Manusia, disamping potensi negatif mampu teraktualisasi secara nyata.

\section{SEPUTAR MAKNA MURABAHAH}

Menurut Arifin (2002:25) murabahah adalah salah satu bentuk jual beli yang bersifat amanah bentuk jual beli ini berlandaskan pada sabda Rasululluh SAW dari Syu'ab ar Rumy RA. " Tiga hal yang di dalamnya terdapat keberkahan: menjual dengan pembayaran tangguh (murabahah), kedua, muqarradah (nama lain dari mudharabah), dan ketiga adalah mencampuri tepung dengan gandum untuk keperluan rumah".

Sedangkan definisi murabahah oleh para fuqaha adalah sebagai penjualan barang seharga biaya/ harga pokok (cost) barang tersebut ditambah mark-up atau margin keuntungan yang disepakati. Fatwa DSN (Dewan Syari'ah Nasional) dijelaskan bahwa yang dimaksud dengan murabahah (DSN 2003:311) adalah menjual suatu barang dengan menegaskan harga belinya kepada pembeli dan pembeli membayarnya dengan harga yang lebih sebagai laba. Menurut PSAK 59 tentang akuntansi perbankan Syari'ah paragraf 52 dijelaskan bahwa murabahah adalah akad jual beli barang dengan menyatakan harga perolehan dan keuntungan (margin) yang disepakati oleh penjual dan pembeli.

\section{Landasan Syari'ah Murabahah}

Secara umum landasan dasar syari'ah Al Murabahah adalah lebih mencerminkan anjuran untuk melakukan usaha, hal ini tampak dari ayat-ayat Al-Qur'an:

"Hai orang-orang yang beriman, janganlah kamu saling memakan harta sesamamu dengan jalan yang bathil, kecuali dengan jalan perniagaan yang berlaku dengan suka sama suka diantara kamu, dan janganlah kamu membunuh dirimu, sesungguhnya Allah maha peryayang kepadamu". (QS. An-Nisa':29).

Dari sini nampak sekali bahwa umat Islam telah berkonsensus dalam keabsahan jual beli, yaitu oleh karena, manusia sebagai anggota masyarakat selalu membutuhkan apa yang dihasilkan dan dimiliki oleh orang lain. Oleh 
karena itu, jual beli adalah salah satu jalan untuk memperolehnya secara sah dan halal.

Macam-macam murabahah

a) Murabahah tanpa Pesanan

Maksudnya ada yang pesan atau tidak, ada yang beli atau tidak, bank syari'ah menyediakan barang dagangannya, penyediaan barang pada murabahah ini tidak terpengaruh atau terkait langsung dengan ada tidaknya pesanan atau pembeli.

b) Murabahah berdasarkan pesanan

Maksudnya, bank syari'ah baru akan melakukan transaksi murabahah atau jual beli apabila ada nasabah yang memesan barang sehingga penyediaan barang baru dilakukan jika ada pesanan. Pengadaan barang ini sangat tergantung atau terkait langsung dengan pesanan atau pembelian barang tersebut.

\section{Rukun Murabahah}

1. Penjual $\left(b a^{\prime} i\right)$

2. Pembeli (musytari)

3. Obyek/barang (mabi')

4. Harga (tsaman)

5. Ijab qabul (sighat)

\section{Syarat-Syarat Murabahah}

Berbagai literatur menyebutkan syarat murabahah yang sama namun untuk memudahkan penulis mengambil pendapat dari Antonio (1999:159), adalah sebagai berikut :

* Penjual memberitahu biaya modal kepada nasabah

* Kontrak pertama harus sah sesuai dengan rukun yang ditetapkan

* Kontrak harus bebas riba

* Penjual harus menjelaskan kepada pembeli bila terjadi cacat atas barang sesudah pembelian.

* Penjual harus menyampaikan semua hal yang berkaitan dengan pembelian, misalnya jika pembelian dilakukan secara hutang. 
Berbicara mengenai pemasaran bila dikaitkan dengan etika seakan sulit untuk menjumpai titik temu. Hal ini disebabkan orang sering beranggapan pemasaran yang merupakan bagian dari bisnis tidak bisa digandengkan dengan etika (Keraf, 1998). Padahal bila dipadukan antara etika dengan pemasaran akan mengantarkan lembaga yang dipimpinnya menjadi sustainable (terus menerus) dan establish (mapan).

Makna etika dalam pandangan masyarakat muslim bukanlah sebuah istilah asing. Namun Istilah ini dikenal sebagai sebuah undang-undang yang mengatur diri manusia dalam beribadah dan bermu'amalaah, berekonomi, agar senantiasa berjalan pada rel yang telah digariskan oleh ajaran yang diyakininya. Dari sini dapat kita lihat bahwa secara harfiah arti dari etika adalah cara seseorang dalam melakukan sesuatu yang dianggap baik (Mulyono, 2006).

Pemasaran merupakan kegiatan pokok yang dilakukan oleh perusahaan untuk tetap bertahan hidup, berkembang dan mendapatkan profit yang tidak bertentangan dengan nilai yang diyakini. Pemasaran tidak dibenarkan jika hanya dikonotasikan dengan penjualan (selling), perdagangan, dan pendistribusian (Candra, 2002). Namun secara umum ketiga pengertian tersebut masuk ke bagian pemasaran. Adapun substansi dari pemasaran adalah bagaimana tercipta kepuasan pelanggan (customer satisfaction), (Kotler 2001), yang akan melahirkan pelanggan loyal (customer loyality).

Untuk memperjelas apa sebenarnya pemasaran sharii'ah bila dibandingkan dengan pemasaran non sharii'ah, bisa dilihat dari beberapa pendapat diantaranya adalah definisi yang diberikan oleh American Association (AMA) yang dikutip oleh Pride dan Ferrell (Farrel, 1993) :

Marketing is an organizational funtion and a set processes for creating, communicating, and delivering value to customer and for managing customer relationships in ways the benefit the organization and its stake holders.

Pemasaran adalah proses perencanaan dan pelaksanaan rancangan, penetapan harga, promosi dan distribusi barang, jasa dan gagasan untuk menciptakan pertukaran yang memenuhi sasaran-sasaran individu dan organisasi.

Definisi ini memberikan gambaran bahwa pemasaran merupakan salah satu dari sekian banyak masalah yang dihadapi perusahaan yakni bagaimana 
kekayaan yang telah diinvestasikan dapat segera kembali dengan membawa sejumlah keuntungan yang diinginkan. Dari sini dibutuhkan perencanaan dalam pelaksanaan, penetapan harga, promosi dan distribusi, proses yang dilakukan untuk memenuhi sasaran dan target yang direncanakan.

\section{Etika Pemasaran dalam Islam}

Kertajaya dan Sula (2006:67) etika pemasaran yang akan menjadi prinsipprinsip bagi syariah marketer dalam menjalankan fungsi-fugsi pemasaran yaitu:

1. Memiliki kepribadian spritual (taqwa)

2. Berprilaku baik dan simpatik (shidiq)

3. Berlaku bisnis dalam bisnis (al-Adl)

4. Bersikap melayani dan rendah hati (khidmad)

5. Tidak suka menjelek-jelekan (ghibah)

6. Tidak melakukan sogok (risywah)

\section{METODE}

Penelitian ini adalah penelitian lapangan (Field Research) tentang pemahaman etika dalam pemasaran produk murabahah, dan implikasinya terhadap strategi pemasaran di Bank Muamalat Indonesia Cabang Malang. Untuk itu penelitian ini menggunakan pendekatan kualitatif karena pendekatan kuantitatif dari positivisme yang berdasarkan pada konsep standar dalam penelitian sosial kurang relevan dalam mengungkap realitas sosial yang beragam.

Penelitian tentang realitas sosial yang bernuansa keagamaan serta menyangkut nilai-nilai yang diimplementasikan oleh komunitas internal Bank Muamalat yakni ajaran etika dalam melakukan pemasaran dapat diteliti dengan metode kualitatif, karena bisa memberikan peluang untuk memahami fenomena menurut pandangan aktor setempat.

\section{PEMBAHASAN}

Pemahaman Tentang Etika Bisnis di Lingkungan Bank Muamalat Indonesia Cabang Malang

Dari hasil wawancara 28 agustus 2007 dengan Account Manager bank Muamalat Indonesia Cabang Malang. Dikatakan bahwa sangat setuju kalau etika 
bisnis memiliki hubungan yang tidak bisa di pisahkan karena dengan etika bisnis akan mengantarkan sebuah lembaga yang sustainable dan establish. Wawancara yang peneliti lakukan rata - rata memiliki pemahaman yang sama akan pentingnya penerapan etika dalam dunia kerja, transaksi dan dalam melakukan relasi saat melayani nasabah.

Hal ini dapat dilihat saat mereka para karyaw an masuk jam kerja yakni sekitar jam 08.00 diadakan permohonan doa bersama kepada sang khalik agar transaksi yang dilakukan senantiasa mendapatkan ridho dariNya, yang dilakukan setiap hari sebelum mulai kerja dan setelah jam kerja selesai yang di pimpin oleh office boy.

Selain itu dalam rangka peningkatan pemahaman etika biasanya karyawan secara bergilir di ikutkan dalam training yang diadakan langsung dari pusat. Bank Muamalat juga mengadakan pengajian seminggu sekali yaitu setiap hari rabu sore jam 18.00 - 19.00 yang di mulai dari sholat magrib berjama'ah dan setelah itu di adakan pengajian yang mendatangkan mubalik dari luar secara bergantian, dan ditutup dengan sholat isya' berjamaah, ini sifatnya adalah wajib bagi semua karyawan untuk mengikuti. Tujuannya adalah untuk meningkatkan spiritual dari pada karyawan dan meningkatkan kebersamaan diantara karyawan.

\section{Implikasi Etika Bisnis dalam Memasarkan Produk Murabahah}

Dari hasil wawancara dengan karyawan Bank Muamalat bahwa komunitas Bank Muamalat senantiasa memiliki kepribadian spiritual (taqwa) yang dicerminkan dalam transaksi bisnis yaitu melakukan usaha adalah sematamata untuk mendapatkan hasil yang halal dan baik. Para karyawan berperilaku benar dan simpatik (shidiq) yang diwujudkan dengan tidak membedakan setiap karyawan yang datang apakah mereka memiliki tabungan banyak atau sebaliknya, berpenampilan necis atau sebaliknya serta memberikan perilaku sama terhadap nasabah yang datang yang diwujudkan dengan tutur kata baik, murah senyum, melayani dengan ekspresi menyenangkan dan tidak cemberut.

Berlaku adil dalam bisnis (Al-Adl) memperoleh hasil usaha hanya melalui perniagaan yang berlaku ridho sama ridho (suka sama suka, kesepakatan bersama), menghindari keraguan yang dapat merugikan secara syari'ah atau 
hukum Islam, menerapkan prinsip kehati-hatian (prudential management) dalam berinvestasi dan pemberian pembiayaan, dan karyawan disini tidak boleh membeda-bedakan dalam memberikan pelayanan kepada nasabah. Dalam hal adil dalam pelayanan adalah karyawan tidak melakukan sogok dalam hal ini tidak adanya praktek suap dalam melancarkan transaksi proses pembiayaan dan lain sebagainya. Mereka yang melakukan transaksi pembiayaan dengan jumlah kecil atau besar adalah sama tanpa adanya sogok (risywah, gravitation), dan janji yang berlebihan.

Dalam wawancara dengan Acount Manager nya bahwa produk Murabahah yang di pasarkan Murabahah berpotensi ekonomi dan benefit karena sistem murabahah adalah jual beli dengan mengambil margin yang disepakati bersama. Namun yang menjadi catatanm walaupun transaksi murabahah memiliki potensi benefit, tidak mau memberikan pembiayaan kepada pabrik rokok walaupun akan memiliki return yang besar.

Harga dari produk murabahah adalah harga yang wajar dan tidak terlalu membebani pada nasabah karena sifatnya adalah menolong nasabah. Harga dari murabahah adalah sebagai alat kompetisi yang sehat antar pelaku perbankan, dan penentuan margin ditentukan dan diukur dengan kemampuan daya beli masyarakat, namun tetap mengacu kepada BI rate nya, namun tetap sesuai dengan kesepakatan bersama.

Dari pelayanan yang dilakukan, harga wajar, berprinsip sama rela dan sama tau, serta hanya memberikan pembiayaan kepada produk yang halal, tidak makruh apalagi haram, seperti: rokok, minuman keras, alat kontrasepsi yang digunakan oleh masyarakat belum waktunya, hal ini memberikan brand tersendiri. Labeling halal, tidak transaksi pada hal makruh memberikan kesan tersendiri dibenak pelanggan yang berimplikasi pada asset, pembiayaan secara umum, DPK, serta kredit macet yang dimiliki oleh lembaga Bank Muamalat Indonesia, hal ini bisa dilihat dalam Financial Performance of Bank Muamalat sebagaimana tabel berikut : 


\section{Financial Performance Of Bank Muamalat}

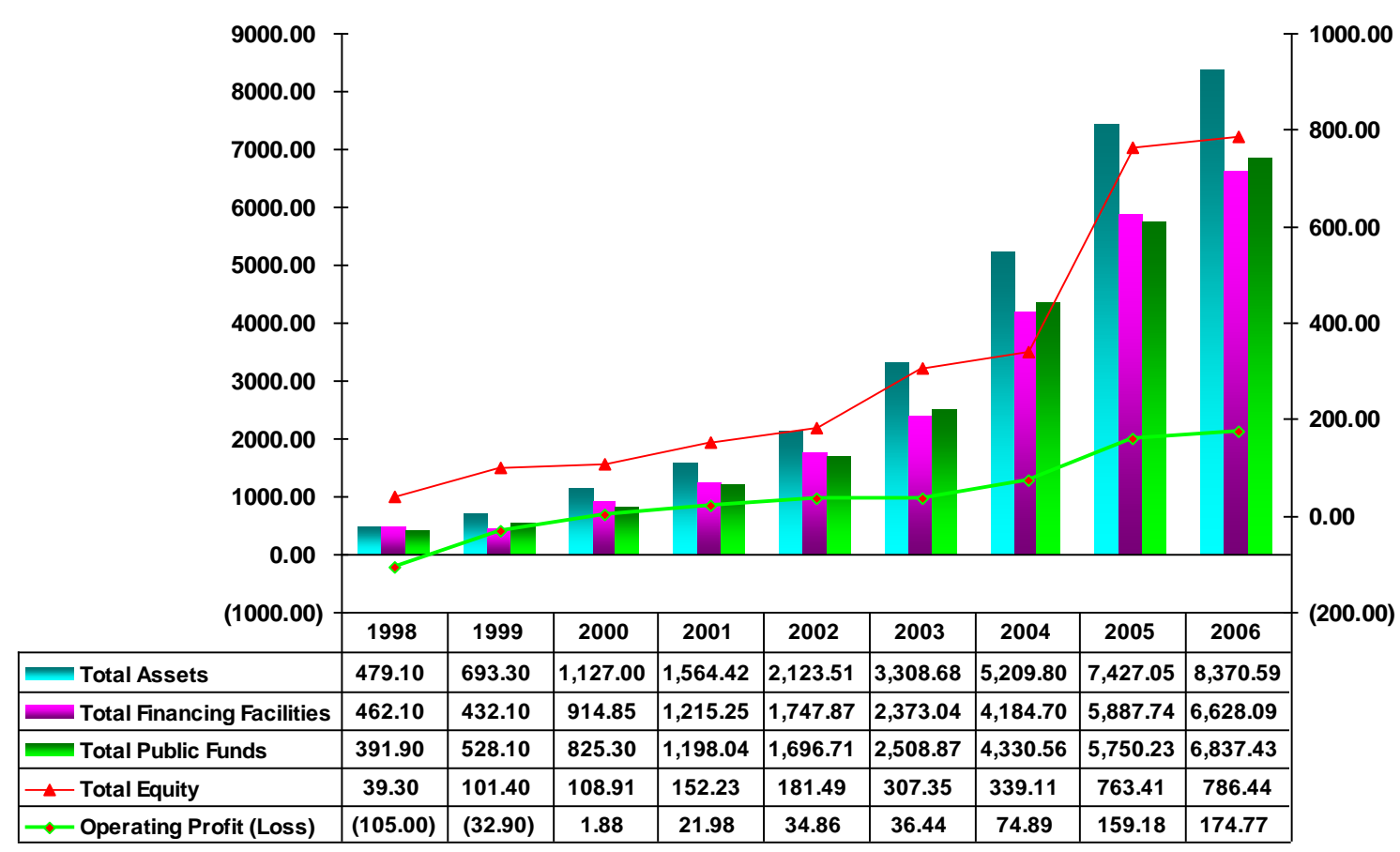

\section{KESIMPULAN}

Berdasarkan pengamatan dan wawancara peneliti menyimpulkan bahwa:

1. Bank Muamalat Indonesia Cabang Malang sangat memahami akan pentingnya penerapan etika dalam kegiatan bisnisnya. Etika mempunyai hubungan yang sangat erat dengan bisnis yang dijalankan, dengan etika membuat bisnis yang dijalankan menjadi sustainable dan establish. Pentingnya implementasi etika dalam bisnis selain untuk tujuan di atas adalah dalam rangka mencari keridloaan Allah SWT.

2. Implikasi pemahaman nilai etika dalam bisnis bagi komunitas Bank Muamalat Indonesia Cabang Malang tercermin dalam memberikan pelayanan nasabah dalam transaksi murabahah, yang dilakukan dengan ramah, baik hati, jujur, tanpa membedakan setiap nasabah yang datang. Dengan aktivitas pemasaran yang dilakukan dengan etika memberikan dampak kepada peningkatan asset, fasilitas pembiayaan, Dana Pihak Ketiga (DPK) serta rendahnya pembiayaan macet karena meningkatnya kepercayaan masyarakat. 


\section{DAFTAR PUSTAKA}

Alois, A, Nugraha. 2001. Prosedur Penelitian Suatu Pendekatan Praktek. Jakarta: PT Rineka Cipta.

Amstrong, Gary. 2001. Prinsip-Prinsip Pemasaran. Edisi ke Delapan. Jilid II. Jakarta: Erlangga.

Badroen, Faisal. 2006. Etika Bisnis. Yogyakarta: Kanisius.

Data Statistik Perbankan Syari'ah, Oktober 2005. Direktorat Perbankan Syari'ah. Bank Indonesia.

Kertajaya, Hermawan \& Muhammad Syakir Sula. 2006. Syari'ah Marketing. Bandung: PT Mizan.

Karim, Adiwarman, A. 2006. Bank Islam Analisis Fiqih dan Keuangan. Jakarta: PT Raja Grafindo Persada.

Keraf, A, Sonny. 1998. Etika bisnis. Yogyakarta: Kanisius.

Kotler, Philip. 2002. Manejemen Pemasaran. Edisi milenium. Jilid 1. Jakarta: PT Prehalindo. 